\section{Editor-in-Chief \\ Barbara McLain - (retired Prof.) \\ University of Hawaii, USA}

The Israeli Journal of Aquaculture (IJA) is an interdisciplinary journal that is dedicated to sharing new research and tested applications of aquaculture

The IJA is devoted to scholarly articles for improved aquaculture practices and related industries

The IJA is a peer-reviewed, open-access, electronic journal

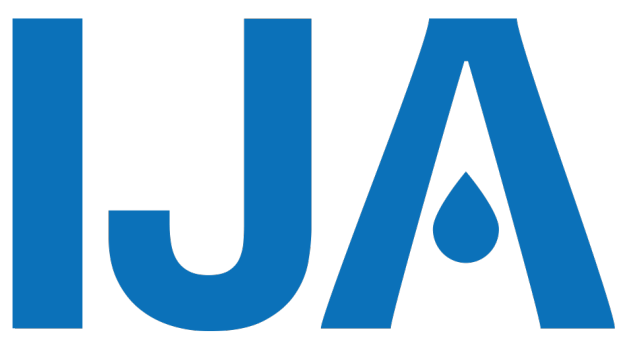

\section{The () Israeli Journal of Aquaculture}

An interdisciplinary online Open Access scientific journal

Published by the

\section{AquacultureHub}

A non-profit organization 501c3

http://www.aquaculturehub.org

in partnership with the

\section{University of Hawaii at Manoa} Library

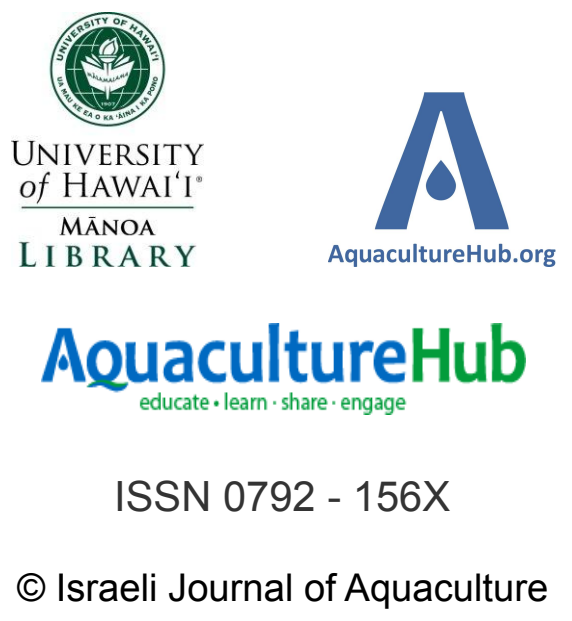




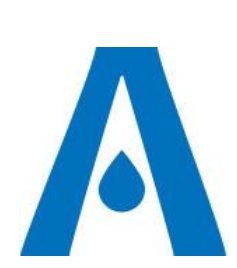

Produced by the AquacultureHub non-profit Foundation the IJA is an open-access, scientific journal, published on http://www.aquaculturehub.org/group/israelijournalofaq uaculturebamidgehija

To read papers free of charge, please register online at the above website.

Sale of IJA papers is strictly forbidden.

\title{
The Effect of Diet on Ovarian Development and Nutritional Tissue Composition of Portunus trituberculatus
}

\author{
Wenjie Hou ${ }^{1 \#}$, Meimei Liu 2, 3\#, Xugan Wu 2, 3, 4*
}

\begin{abstract}
${ }^{1}$ Shanghai Fisheries Research Institute and Shanghai Fisheries Technical Extension Station, Shanghai 200433, China

${ }^{2}$ Key Laboratory of Exploration and Utilization of Aquatic Genetic Resources, Ministry of Education, Shanghai Ocean University, Shanghai, 201306, China

${ }^{3}$ Collaborative Innovation Center of Aquatic Animal Breeding certificated by Shanghai municipal education commission, Shanghai Ocean University, Shanghai 201306, China

${ }^{4}$ Collaborative Innovation Center of Mari-culture industry in East China Sea, Ningbo University, Ningbo 315211, Zhejiang, China
\end{abstract}

Keywords: Portunus trituberculatus; fattening diets; ovarian development; nutritional quality

\begin{abstract}
This study investigated the effects of feeding trash fish (TF), formulated diet (FD), and mixed diets (MD) on ovarian development, fattening performance, and nutritional quality of $P$. trituberculatus. Formulated diet treatment resulted in lower gonadosomatic index, hepatosomatic index, meat yield, and total edible yield than the other treatments. It also showed lower protein $(7.88 \%)$, lipid, and ash content in hepatopancreas and muscle, compared to the other treatments. Different diets significantly affected the contents of $\mathrm{C} 16: 0, \mathrm{C} 18: 1 \mathrm{n} 9, \mathrm{C} 18: 2 \mathrm{n} 6, \mathrm{C} 18: 3 \mathrm{n} 3$ and $\mathrm{C} 20: 5 \mathrm{n} 3$ of hepatopancreas. FD treatment resulted in lower essential amino acids and non-essential amino acid contents in the muscle compared to TF and MD treatments. The highest and the lowest essential amino acids scores were found in the TF and FD treatments, respectively. In conclusion, these results indicated that FD is not suitable and requires further development for sub-adult crabs, while MD would be the recommended for fattening female $P$. trituberculatus.
\end{abstract}

\footnotetext{
* Corresponding author. Email: wuxugan@hotmail.com
} 


\section{Introduction}

The swimming crab Portunus trituberculatus, is one of the most important mariculture crab species in China, with an annual production of 125,317 tons in 2017 (Bureau of Fisheries and Management, 2018). The female $P$. trituberculatus with fully developed ovaries generally produces the highest edible yields, nutritional value, and unique flavor. Therefore, these fully developed females are very popular with consumers, and are sold at substantially higher prices than the thin crabs or females with undeveloped ovaries (Wu et al., 2014). Although aquaculture production of $P$. trituberculatus is mainly implemented in earthen ponds, pond-reared females generally have poor ovarian development with light coloration (Wu et al., 2010a). Therefore, high-quality females used for food or as broodstock are normally collected from the wild, at sea, where they are at risk of overfishing (Wu et al., 2010a).

Previous studies have shown that appropriate diet can promote ovarian development and improve nutritional value for female $P$. trituberculatus maturation, puberty molt, and fattening of immature ovaries for pond-culture of $P$. trituberculatus, particularly in the late culture period (Wu et al., 2014). Trash fish and low value bivalves/shellfish are commonly used as fattening food for pond-culture of $P$. trituberculatus. However, compared to formulated diets, these natural foods have many disadvantages, including fluctuating availability, unbalanced nutrition, high cost, negative impact on water quality, and could be pathogen carriers (Duan et al., 2013). The development of cost-effective fattening diets is therefore urgent for attaining the sustainable development of the farming of $P$. trituberculatus. Previous studies focused on the nutritional requirements and feed formulations for juveniles $P$. trituberculatus (Ding et al., 2010; Zhang et al., 2014; Li et al., 2015; Jin et al., 2015). However, there is no information about how adult $P$. trituberculatus would respond to such diets.

The best market time in the coastal area of Eastern China for pond-reared female $P$. trituberculatus generally occurs from the end of December to March of the following year, when high market prices of female crabs with mature ovaries are achieved (Wu et al., 2014). Unfortunately, as the temperature of pond water lowers during the end of that period, pond-reared crabs are already in an over-wintering stage and buried under sand/mud at bottom of the pond, making harvesting more difficult (Qiao and Gu, 2012). In recent years, single crab culture in individual baskets (SCCIB) has become an emerging method that has many advantages, including facilitating harvesting, improving survival rates, and reducing labor (Wang et al., 2013). Previous studies have demonstrated that the SCCIB system can ensure normal ovarian development by increasing water temperature of indoor tanks. Therefore, the SCCIB system has the potential to be applied to indoor culture of female $P$. trituberculatus (Wang et al., 2013; Pan et al., 2015).

This study was conducted to investigate the effects of trash fish, formulated diet, and mixed diets on ovarian development, fattening performance, and nutritional quality of female $P$. trituberculatus using a single crab culture system to rear female P.trituberculatus in indoor tanks. Females cultured in traditional outdoor earth ponds were utilized as the control treatment. The results of the present study provide valuable information for the improvement of fattening technology and formulating diets for the $P$. trituberculatus farming industry.

Crab sources and experimental design.

The present experiment was conducted at Qidong Research Station of Shanghai Fisheries Institute on Qidong County, Jiangsu Province, P.R. China. In late October 2014, approximately 100 adult female $P$. trituberculatus were obtained from outdoor earth ponds. At the beginning of March, all earthen ponds were treated with chlorinated lime. About two weeks later, similar-sized, active, and intact juveniles (body weight: 5-10 $\mathrm{g} /$ individual crab) were stocked in the pond with the density of 3-4 crabs/m2, and the ratio of male and female was 2:8. During the culture period, the frozen mysis Neomysis japonica and trash fish Collichthys lucidus were fed to pond-reared $P$. trituberculatus. The crabs were fed twice per day and the feeding ration was approximately $3-10 \%$ of total crab biomass, however the specific value was dependent on residual feed and water temperature. 
The experimental crabs completed puberty molting and weighed between 150-250g. Healthy and intact females were selected and stocked in 72 baskets (Length $\times$ Width $\times$ Depth $=33 \times 27.5 \times 35 \mathrm{~cm}$ ) for the subsequent experiment, whereby each female was reared individually in one basket. Baskets were floated in three concrete tanks (Length $\times$ Width $\times$ Depth $=5.8 \times 2.4 \times 1.8 \mathrm{~m}$ ), and they all had uniform holes around the wall, ensuring an equal water exchange between the tanks and baskets. The water depth of each basket was around $25 \mathrm{~cm}$ and approximately $5-6 \mathrm{~cm}$ of sand was provided on the bottom of each basket for burying behavior (Pan et al., 2015). Prior to the commencement of the experiment, the crabs were acclimated for one week to the experimental conditions and fed trash fish (Collichthys lucidus). There were three dietary treatments in this study: i) only trash fish (TF); ii) only formulated diet (FD); and iii) a mixed diet (MD) with the alternation of trash fish for three days, formulated diet for three days, and then clam (Aloididae aloidis) meat for one day. Each treatment consisted of 24 females, each in an individual basket. The experimental trash fish, primarily spinyhead croaker Collichthys lucidus, and clams Aloididae aloidis, were purchased from local fishing boats and clam farm, respectively; while the formulated diet was pelleted by a commercial feed company (Zhejiang Xinxin Feed Co., Ltd, Jiaxing, Zhengjiang Province, China). The diameter of the pellets was $4 \mathrm{~mm}$. All experimental diets were prepared in bulk and stored in a $-20^{\circ} \mathrm{C}$ freezer until used. The nutritional composition of three diets is shown in Table 1.

Table 1. The proximate compositions and fatty acid profiles of three different diets

\begin{tabular}{|c|c|c|c|}
\hline Biochemical composition & Trash fish & Formulated diet & Clam meat \\
\hline Moisture (\% wet weight) & $77.26 \pm 0.60^{\mathrm{b}}$ & $11.47 \pm 0.16^{\mathrm{a}}$ & $78.66 \pm 0.25^{c}$ \\
\hline Protein (\% dry weight) & $59.13 \pm 1.15^{\mathrm{b}}$ & $38.89 \pm 0.23^{a}$ & $66.91 \pm 1.16^{c}$ \\
\hline Total lipids (\% dry weight) & $7.56 \pm 1.85^{a}$ & $9.83 \pm 0.30^{\mathrm{b}}$ & $7.81 \pm 0.68^{a}$ \\
\hline Ash (\% dry weight) & $17.73 \pm 0.68^{c}$ & $9.70 \pm 0.10^{a}$ & $10.80 \pm 0.24^{b}$ \\
\hline Fatty acids ( $\%$ total fatty acids) & $92.97 \pm 0.79^{b}$ & $99.30 \pm 0.42^{c}$ & $86.90 \pm 8.23^{a}$ \\
\hline C14:0 & $4.80 \pm 0.77^{b}$ & $2.20 \pm 0.12^{\mathrm{a}}$ & $1.68 \pm 0.17^{\mathrm{a}}$ \\
\hline C16:0 & $22.31 \pm 0.25^{b}$ & $17.98 \pm 0.67^{a}$ & $16.79 \pm 0.96^{b}$ \\
\hline C17:0 & $0.52 \pm 0.06^{a}$ & -- & $0.74 \pm 0.08^{\mathrm{b}}$ \\
\hline C18:0 & $6.97 \pm 0.08^{b}$ & $4.23 \pm 0.38^{a}$ & $4.78 \pm 0.23^{a}$ \\
\hline $\mathrm{C} 22: 0$ & $0.52 \pm 0.01$ & - & - \\
\hline$\Sigma$ SFA & $35.12 \pm 0.93^{b}$ & $24.59 \pm 0.56^{a}$ & $24.03 \pm 0.99^{a}$ \\
\hline C16:1 & $8.63 \pm 0.28^{c}$ & $1.53 \pm 0.08^{a}$ & $5.96 \pm 0.26^{b}$ \\
\hline C18:1n9 & $10.88 \pm 0.91^{b}$ & $24.62 \pm 0.70^{c}$ & $3.92 \pm 1.33^{\mathrm{a}}$ \\
\hline C18:1n7 & $4.10 \pm 0.22$ & $3.17 \pm 1.08$ & $3.55 \pm 0.34$ \\
\hline C20:1 & $1.06 \pm 0.09^{b}$ & $0.72 \pm 0.11^{a}$ & $1.08 \pm 0.22^{b}$ \\
\hline C24:1 & $0.58 \pm 0.09$ & - & $0.42 \pm 0.09$ \\
\hline ¿MUFA & $25.25 \pm 0.84^{b}$ & $30.57 \pm 0.50^{c}$ & $15.59 \pm 2.05^{a}$ \\
\hline $\mathrm{C} 18: 2 \mathrm{n} 6$ & $1.16 \pm 0.11^{\mathrm{a}}$ & $23.83 \pm 0.17^{b}$ & $1.72 \pm 0.43^{\mathrm{a}}$ \\
\hline$C 18: 3 n 3$ & $0.27 \pm 0.11^{\mathrm{a}}$ & $3.62 \pm 0.27^{c}$ & $1.61 \pm 0.56^{b}$ \\
\hline$C 20: 2 n 6$ & - & $0.54 \pm 0.11$ & $0.60 \pm 0.37$ \\
\hline$C 20: 4 n 6$ & $1.71 \pm 0.18^{b}$ & $0.52 \pm 0.05^{\mathrm{a}}$ & $1.70 \pm 0.16^{b}$ \\
\hline$C 20: 5 n 3$ & $13.47 \pm 0.76^{b}$ & $4.51 \pm 0.31^{a}$ & $18.17 \pm 0.68^{c}$ \\
\hline$C 22: 6 n 3$ & $12.35 \pm 0.57^{b}$ & $6.82 \pm 0.46^{a}$ & $15.27 \pm 0.40^{c}$ \\
\hline$\Sigma$ PUFA & $29.25 \pm 0.69^{a}$ & $40.29 \pm 0.45^{c}$ & $39.07 \pm 1.32^{b}$ \\
\hline n3PUFA & $26.10 \pm 0.59^{b}$ & $14.95 \pm 0.68^{a}$ & $35.06 \pm 1.57^{c}$ \\
\hline n6PUFA & $3.15 \pm 0.14^{\mathrm{a}}$ & $25.35 \pm 0.58^{c}$ & $4.02 \pm 0.38^{b}$ \\
\hline$n 3 / n 6$ & $8.28 \pm 0.28^{b}$ & $0.59 \pm 0.03^{a}$ & $8.81 \pm 1.15^{b}$ \\
\hline$\Sigma$ HUFA & $27.54 \pm 0.64^{b}$ & $11.85 \pm 0.61^{a}$ & $35.14 \pm 1.14^{c}$ \\
\hline DHA/EPA & $0.92 \pm 0.09^{a b}$ & $1.51 \pm 0.23^{b}$ & $0.84 \pm 0.02^{\mathrm{a}}$ \\
\hline ARA/EPA & $0.13 \pm 0.01$ & $0.12 \pm 0.02$ & $0.09 \pm 0.01$ \\
\hline
\end{tabular}

Notes: Data are presented as mean \pm SD. Values in the same line with different superscripts were significantly different $(P<0.05)$. The fatty acid with less than $0.4 \%$ of total fatty acids was not shown in the tables. SFA: saturated fatty acids; MUFA: mono-unsaturated fatty acids; PUFA: poly-unsaturated fatty acids; HUFA: highly-unsaturated fatty acids; $n-3 / n-6$ : the ratio of $\Sigma n-3 P U F A / \Sigma n-6 P U F A$.

To understand the ovarian development and nutritional composition of pond-reared females, 24 pond-reared females were used as the control treatment (PRC). These females were always reared in traditional outdoor earth ponds and were fed trash fish during the fattening period. 
Culture management and crab sampling.

The experimental crabs were fed the designated diets once a day at 19:00. The amount of feed was adjusted according to the water temperature and food residues. When the water temperature was above $16^{\circ} \mathrm{C}$ the feeding ration was set at around $4 \%$ and $1 \%$ of total biomass for natural foods and formulated diet, respectively. These values were reduced to $1.5 \%$ and $0.5 \%$ when the water temperature was below $16^{\circ} \mathrm{C}$.

The crabs were not fed when the water temperature was below $11^{\circ} \mathrm{C}$, as they are known not to consume food under such conditions (Pan et al, 2015). Prior to feeding, feces and uneaten feed were removed by siphoning, and mortality was recorded every day. Water quality was maintained by recirculation, including a filtering medium composed of polyester wool, activated charcoal, corallite, and gravel in three connected reservoir tanks. The filtered water was recirculated at the speed of $100 \mathrm{~L} / \mathrm{min}$ to each rearing tank via a water pump (12 times/day). During the experiment, water temperature was not controlled when it was between $11-21^{\circ} \mathrm{C}$ (Figure 1). Light was provided by outdoor natural light cycle. Salinity, $\mathrm{pH}$, dissolved oxygen (DO), ammonia and nitrite levels were monitored regularly and maintained at optimal levels for $P$. trituberculatus (Xie et al., 2002): salinity: $23-25 \mathrm{~g} / \mathrm{L} ; \mathrm{pH}: 7.0-9.0$; DO: $>5 \mathrm{mg} / \mathrm{L}$; ammonia: $<0.4 \mathrm{mg} / \mathrm{L}$ and nitrite: $<0.10 \mathrm{mg} / \mathrm{L}$, respectively. The feeding trial lasted 8 weeks and ended on December 30, 2014.
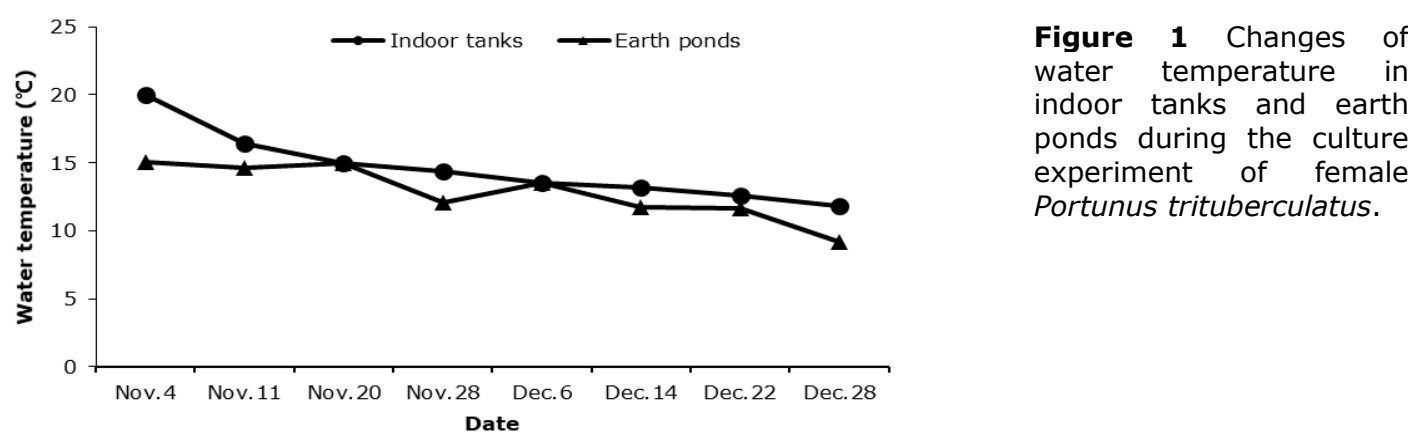

Prior to the experiment, ten crabs were randomly sampled and dissected to obtain the initial gonadsomatic index (GSI), hepatosomatic index (HSI), and meat yield (MY), which were $2.41 \%, 5.10 \%$ and $26.93 \%$, respectively. All crabs were starved two days prior to the final sampling. Twelve surviving crabs from each treatment were randomly sampled for the dissection. Before the dissection, individual crabs were blotted dry with a paper towel. Then, the wet weight of the crabs was measured, their ovaries, hepatopancreas and meat from all body parts were then carefully collected and weighed separately and stored at $-40^{\circ} \mathrm{C}$ until analysis. The GSI, HSI, MY and total edible yield (TEY) of the crabs were calculated using the following formulas:

GSI $(\%)=100 \times$ Gonad wet weight/Body wet weight

HSI $(\%)=100 \times$ Hepatopancreas wet weight/Body wet weight.

MY $(\%)=100 \times$ Meat wet weight/Body wet weight.

TEY $(\%)=\mathrm{MY}+\mathrm{HSI}+\mathrm{GSI}$ (Where MY = Meat yield, HSI= Hepatosomatic index and

GSI $=$ Gonadal somatic index).

Proximate composition.

Moisture content of each frozen sample was obtained by drying the tissue in an oven set at $70^{\circ} \mathrm{C}$ for $24 \mathrm{~h}$. Prior to lipid analysis, all samples were freeze-dried and homogenized separately. The contents of crude protein (Kjeldahl method, using a $6.25 \mathrm{~N}$ to protein conversion factor) and ash (using a muffle furnace at $550^{\circ} \mathrm{C}$ until constant weight) were analyzed according to AOAC procedures (AOAC, 1995). Total lipid was extracted with chloroform-methanol $(2: 1, \mathrm{v} / \mathrm{v})$ (Folch et al., 1957). There were six replicates for proximate analysis of each treatment. 
Fatty acids.

Five individual replicates per treatment were used. Fatty acid methyl esters (FAME) were prepared by transesterification with boiling $14 \%$ borontrifluoride/methanol $(\mathrm{w} / \mathrm{w})$ (Morrison and Smith, 1964). FAME were analyzed by GC-FID (Agilent 7890) fitted with an Omegawax 320 fused silica capillary column (30 m × $0.32 \mathrm{~mm}$; Supelco, Billefonte, PA, USA). Detailed methods were provided by Wu et al. (2010b). Fatty acids were reported as percentage of total fatty acids.

Amino acids.

The amino acids content was analyzed according to the method described by Chen et al. (2007). Each sample ( $0.1 \mathrm{~g})$ was weighed and placed in a $40 \mathrm{~mL}$ hydrolyzation tube, and $8 \mathrm{~mL}$ of $6.0 \mathrm{M} \mathrm{HCl}$ solution was added. The hydrolyzation tube was then vacuumed and filled with nitrogen at $110^{\circ} \mathrm{C}$ for $24 \mathrm{~h}$. The resulting reaction mixture was diluted with distilled water to a volume of $50 \mathrm{~mL}$ and centrifuged at $5000 \mathrm{rpm}$ and the hydrolyzate filtered. $1 \mathrm{~mL}$ of hydrolyzate was subsequently sampled and vacuum dried at $50^{\circ} \mathrm{C}$ to remove $\mathrm{HCl}$. The hydrolyzate was then dissolved in $2-5 \mathrm{~mL}$ of $0.02 \mathrm{M} \mathrm{HCl}$ and $1 \mu \mathrm{L}$ of supernatant sample was used for amino acid analysis on a Sykam S-433D automatic amino acid analyzer (Sykam $\mathrm{GmbH}$, Eresing, Germany). For tryptophan analysis, the preweighed samples were hydrolyzed in $5 \mathrm{M} \mathrm{NaOH}$ containing $5 \% \mathrm{SnCl} 2(\mathrm{w} / \mathrm{v})$ for $20 \mathrm{~h}$ at $110^{\circ} \mathrm{C}$. After hydrolysis, the hydrolysate was neutralized with $6 \mathrm{M} \mathrm{HCl}$, and then centrifuged at $2659 \times \mathrm{g}$ and filtered by filter paper. The subsequent analysis procedure was similar to the methods described above. The determination of methionine and cysteine was based on the methods of oxidation with performic acid and hydrolysis (Spindler et al., 1985). The identity and quantity of the amino acids were assessed by comparing the retention times and peak areas of the standard amino acids (SigmaAldrich, St. Louis. MO, USA). Three replicates for amino acid analysis of each treatment were used.

The essential amino acids score (EAAS), was calculated using the following formula $(\mathrm{FAO} / \mathrm{WHO} / \mathrm{UNU}, 1985):$ EAAS $=100 \times$ essential amino acids content of the sample/FAO reference for essential amino acids content, where amino acids content was expressed as milligram individual amino acids per gram total protein $(\mathrm{mg} / \mathrm{g})$.

Statistics analysis.

All data were presented as mean \pm standard deviation (SD). Homogeneity of variance of data was tested with Levene's test. When necessary, arcsine - square root or logarithmic transformation was performed prior to analysis. One - way ANOVA was used to determine the differences among different treatments. If any significant difference was detected, Tukey's multiple range test was used as the means separation procedure. When a normal distribution and/or homogeneity of the variances were not achieved, data were subjected to the Kruskal-Wallis $\mathrm{H}$ nonparametric test followed by the Games-Howell nonparametric multiple comparison test $\mathrm{P}<0.05$ was regarded as the statistically significant level. All statistics were performed using SPSS package (version 16.0).

\section{Results}

The biochemical components of three diets are reported in Table 1 . The formulated diet had the lowest contents of moisture, protein, and ash, and the highest level of total lipids, while the clam meat had the highest moisture and protein levels, and the lowest content of total lipids. Among the three diets, the trash fish diet produced the intermediate levels of moisture and protein, but the highest ash content $(P<0.05)$. The highest level of total saturated fatty acids ( $\Sigma$ SFA) was found from the trash fish diet, meanwhile the formulated diet and clam meat produced similar levels; formulated diet had the highest level of total monounsaturated fatty acids ( 2 MUFA), with C18:1n9 being the major constituent. Formulated diet had the higher percentages of C18:2n6 and total polyunsaturated fatty acids ( P PUFA), but the lower levels of 20:5n3, 22:6n3 and total high unsaturated fatty acids ( HUFA) than the other diets. As shown in Table 2, formulated diet had the significantly lower levels of total essential amino acids ( $\Sigma E A A)$ and non-essential amino acids $(\Sigma N E A A)$ than trash fish and clam meat $(P<0.05)$. Trash fish had the highest $\Sigma E A A$ content and the EAA/TAA ratio, while clam meat had the highest $\Sigma$ NEAA content among three diets $(P<0.05)$. 
Table 2. The amino acids compositions of different diets (\% dry weight)

\begin{tabular}{llll}
\hline Amino acids & Trash fish & Formulated diet & Clam meat \\
\hline Isoleucine & $2.64 \pm 0.03^{\mathrm{b}}$ & $1.57 \pm 0.01^{\mathrm{a}}$ & $2.64 \pm 0.03^{\mathrm{b}}$ \\
Leucine & $4.64 \pm 0.05^{\mathrm{c}}$ & $2.77 \pm 0.02^{\mathrm{a}}$ & $4.19 \pm 0.05^{\mathrm{b}}$ \\
Lysine & $5.15 \pm 0.06^{\mathrm{c}}$ & $2.24 \pm 0.01^{\mathrm{a}}$ & $4.58 \pm 0.05^{\mathrm{b}}$ \\
Methionine & $1.85 \pm 0.10^{\mathrm{b}}$ & $0.89 \pm 0.04^{\mathrm{a}}$ & $1.76 \pm 0.03^{\mathrm{b}}$ \\
Cystine & $1.15 \pm 0.14^{\mathrm{b}}$ & $0.53 \pm 0.04^{\mathrm{a}}$ & $1.19 \pm 0.11^{\mathrm{b}}$ \\
Phenylalanine & $2.67 \pm 0.03^{\mathrm{c}}$ & $1.73 \pm 0.01^{\mathrm{a}}$ & $2.37 \pm 0.03^{\mathrm{b}}$ \\
Tyrosine & $2.03 \pm 0.02^{\mathrm{b}}$ & $1.31 \pm 0.00^{\mathrm{a}}$ & $2.35 \pm 0.03^{\mathrm{c}}$ \\
Threonine & $2.55 \pm 0.04^{\mathrm{b}}$ & $1.48 \pm 0.01^{\mathrm{a}}$ & $2.71 \pm 0.03^{\mathrm{c}}$ \\
Valine & $2.87 \pm 0.03^{\mathrm{c}}$ & $1.81 \pm 0.01^{\mathrm{a}}$ & $2.76 \pm 0.03^{\mathrm{b}}$ \\
Tryptophan & $0.88 \pm 0.04^{\mathrm{c}}$ & $0.58 \pm 0.04^{\mathrm{a}}$ & $0.73 \pm 0.04^{\mathrm{b}}$ \\
EAA & $26.42 \pm 0.46^{\mathrm{c}}$ & $14.92 \pm 0.03^{\mathrm{a}}$ & $25.29 \pm 0.35^{\mathrm{b}}$ \\
Aspartic acid & $5.93 \pm 0.09^{\mathrm{b}}$ & $3.43 \pm 0.02^{\mathrm{a}}$ & $6.35 \pm 0.08^{\mathrm{c}}$ \\
Serine & $2.48 \pm 0.04^{\mathrm{b}}$ & $1.66 \pm 0.01^{\mathrm{a}}$ & $2.59 \pm 0.03^{\mathrm{b}}$ \\
Glutamic acid & $8.59 \pm 0.11^{\mathrm{b}}$ & $6.67 \pm 0.05^{\mathrm{a}}$ & $8.83 \pm 0.11^{\mathrm{b}}$ \\
Glycine & $3.93 \pm 0.04^{\mathrm{b}}$ & $1.93 \pm 0.02^{\mathrm{a}}$ & $5.18 \pm 0.07^{\mathrm{c}}$ \\
Alanine & $3.68 \pm 0.04^{\mathrm{b}}$ & $1.91 \pm 0.02^{\mathrm{a}}$ & $4.69 \pm 0.07^{\mathrm{c}}$ \\
Histidine & $2.15 \pm 0.04^{\mathrm{c}}$ & $1.19 \pm 0.02^{\mathrm{a}}$ & $1.87 \pm 0.06^{\mathrm{b}}$ \\
Arginine & $3.54 \pm 0.05^{\mathrm{b}}$ & $2.42 \pm 0.01^{\mathrm{a}}$ & $4.42 \pm 0.00^{\mathrm{c}}$ \\
Proline & $2.24 \pm 0.01^{\mathrm{c}}$ & $2.08 \pm 0.03^{\mathrm{a}}$ & $2.17 \pm 0.03^{\mathrm{b}}$ \\
NEAA & $32.00 \pm 0.43^{\mathrm{b}}$ & $21.29 \pm 0.17^{\mathrm{a}}$ & $36.09 \pm 0.45^{\mathrm{c}}$ \\
TAA & $58.42 \pm 0.89^{\mathrm{b}}$ & $36.21 \pm 0.20^{\mathrm{a}}$ & $61.38 \pm 0.80^{\mathrm{b}}$ \\
EAA/TAA & $0.45 \pm 0.00$ & $0.41 \pm 0.00$ & $0.41 \pm 0.00$ \\
\hline Notes: Data $w$ & $\mathrm{p}$ ( & &
\end{tabular}

Notes: Data were presented as mean \pm SD. Values in the same line with different superscripts were significantly different $(P<0.05)$; EAA: essential fatty acids; NEAA: non-essential fatty acids; TAA: total amino acids.

Different feeding modes had a significant effect on the survival rate for female $P$. trituberculatus (Figure 2). At the $5^{\text {th }}$ week of the culture experiment, the formulated diet treatment (FD) produced a higher survival rate than the trash fish treatment (TF) and mixed diet treatment (MD). In TF and MD, the major mortality was recorded during the period between the $5^{\text {th }}$ and the $8^{\text {th }}$ week. At the end of experiment, FD treatment had the highest survival rate, while the lowest survival (58.33\%) was found in TF treatment (Table 3). TF and MD had significantly higher GSI than FD. However, all the three indoor dietary treatments had significantly higher $(P<0.05)$ GSI compared to the pond-reared control treatment $(P R C)$. FD had significantly lower $(P<0.05)$ HSI than PRC, and there was no significant difference for HSI among the other treatments. For meat yield (MY), TF had the largest value among the four treatments $(P<0.05)$. MD and PRC had the middle level of MY among the treatments, while the lowest MY was found from the FD. Overall, TEY had the similar trend as MY among the four treatments.

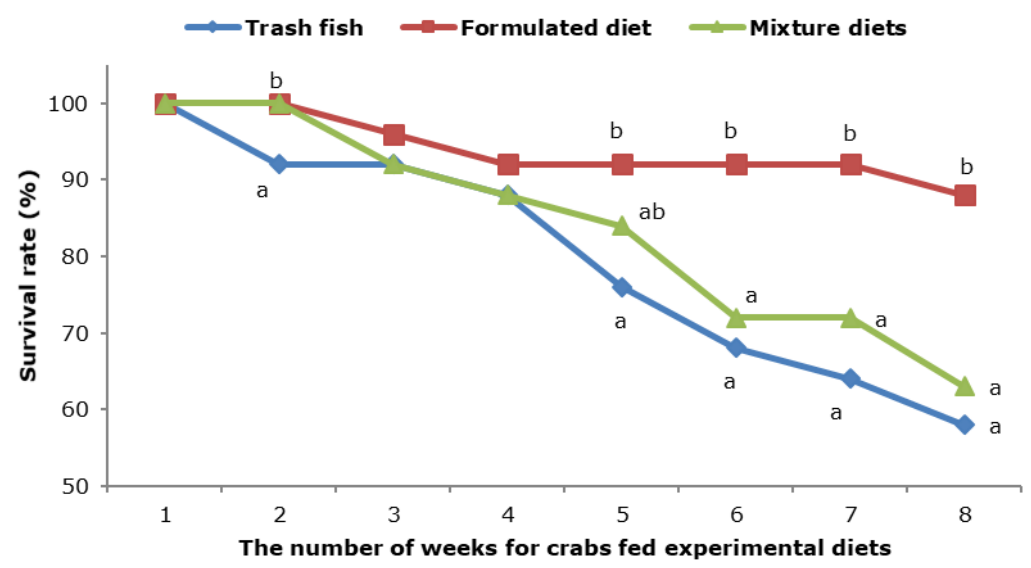

Figure 2 Time-course of survival rate for the female Portunus trituberculatus fed the different diets. The values within the same weeks without the same letter are significantly different $(P<0.05)$ 
Table 3. The effects of different feeding models on survival, ovarian development and edible yields of female Portunus trituberculatus (\%)

\begin{tabular}{lllll}
\hline \multirow{2}{*}{ Treatments } & $\begin{array}{l}\text { Trash } \\
\text { fish }\end{array}$ & $\begin{array}{l}\text { Formulated } \\
\operatorname{diet}(F D)\end{array}$ & $\begin{array}{l}\text { Mixture diets } \\
(M D)\end{array}$ & $\begin{array}{l}\text { Pond-reared control } \\
(P R C)\end{array}$ \\
\hline Survival & $58.33 \pm 7.21^{\mathrm{a}}$ & $87.50 \pm 0.00^{\mathrm{b}}$ & $62.50 \pm 12.50^{\mathrm{a}}$ & -- \\
Gonadosomatic index (GSI) & $9.00 \pm 0.47^{\mathrm{c}}$ & $8.21 \pm 1.06^{\mathrm{b}}$ & $9.05 \pm 0.63^{\mathrm{c}}$ & $6.92 \pm 1.25^{\mathrm{a}}$ \\
Hepatosomatic index (HSI) & $7.09 \pm 0.75^{\mathrm{ab}}$ & $6.57 \pm 0.90^{\mathrm{a}}$ & $7.29 \pm 0.67^{\mathrm{ab}}$ & $7.78 \pm 1.04^{\mathrm{b}}$ \\
Meat yield (MY) & $30.51 \pm 1.91^{\mathrm{b}}$ & $27.50 \pm 3.75^{\mathrm{a}}$ & $28.12 \pm 3.63^{\mathrm{ab}}$ & $28.68 \pm 2.44^{\mathrm{ab}}$ \\
Total edible rate (TEY) & $46.62 \pm 2.02^{\mathrm{b}}$ & $42.22 \pm 4.68^{\mathrm{a}}$ & $44.46 \pm 3.97^{\mathrm{ab}}$ & $43.38 \pm 4.04^{\mathrm{ab}}$ \\
\hline
\end{tabular}

Notes: Data were presented as mean \pm SD $(n=12)$, and the replicates for survival were three. Values in the same line with different superscripts were significantly different $(P<0.05)$.

Table 4 shows the proximate composition of three edible tissues of female $P$. trituberculatus. In terms of ovaries, there were no significant differences in the levels of moisture, protein, and lipids among three feeding modes, while TF and PRC had significantly higher ash contents than MD and FD. As for the proximate composition of hepatopancreas, FD had significantly lowest contents of protein, lipid, and ash among all treatments $(P<0.05)$. FD had significantly higher moisture content in muscle than TF and MD $(P<0.05)$. TF had significantly higher protein level than the PRC $(P<0.05)$, and no significant difference was observed on the protein level between FD and MD. Moreover, TF and PRC had significantly higher ash content in the muscle than the other treatments $(P<0.05)$.

Table 4. The effects of different feeding models on proximate composition of the edible tissues of female Portunus trituberculatus (\% wet weight)

\begin{tabular}{lllll}
\hline Tissue & $\begin{array}{l}\text { Trash fish } \\
\text { (TF) }\end{array}$ & $\begin{array}{l}\text { Formulated diet } \\
\text { (FD) }\end{array}$ & $\begin{array}{l}\text { Mixture diets } \\
\text { (MD) }\end{array}$ & $\begin{array}{l}\text { Pond-reared control } \\
\text { (PRC) }\end{array}$ \\
\hline $\begin{array}{l}\text { Ovary } \\
\text { Moisture }\end{array}$ & $51.58 \pm 1.96$ & $50.87 \pm 1.63$ & $50.39 \pm 0.83$ & $50.43 \pm 1.00$ \\
$\quad$ Protein & $29.14 \pm 1.31$ & $30.31 \pm 0.84$ & $29.79 \pm 0.31$ & $30.23 \pm 0.56$ \\
$\quad$ Lipid & $13.93 \pm 0.52$ & $14.11 \pm 0.63$ & $13.51 \pm 0.61$ & $13.64 \pm 0.35$ \\
$\quad$ Ash & $4.08 \pm 0.30^{\mathrm{b}}$ & $3.29 \pm 0.22^{\mathrm{a}}$ & $2.98 \pm 0.33^{\mathrm{a}}$ & $4.30 \pm 0.30^{\mathrm{b}}$ \\
Hepatopancreas & & & & \\
$\quad$ Moisture & $54.52 \pm 5.22$ & $60.30 \pm 8.28$ & $56.60 \pm 1.57$ & $56.44 \pm 4.81$ \\
Protein & $9.99 \pm 0.35^{\mathrm{b}}$ & $7.88 \pm 1.49^{\mathrm{a}}$ & $10.39 \pm 0.91^{\mathrm{b}}$ & $9.85 \pm 0.72^{\mathrm{b}}$ \\
Lipid & $28.08 \pm 3.32^{\mathrm{b}}$ & $19.85 \pm 4.76^{\mathrm{a}}$ & $27.08 \pm 2.04^{\mathrm{b}}$ & $28.39 \pm 4.10^{\mathrm{b}}$ \\
$\quad$ Ash & $1.96 \pm 0.18^{\mathrm{b}}$ & $1.48 \pm 0.09^{\mathrm{a}}$ & $1.67 \pm 0.11^{\mathrm{a}}$ & $1.75 \pm 0.23^{\mathrm{ab}}$ \\
Muscle & & & & \\
Moisture & $75.24 \pm 1.26^{\mathrm{a}}$ & $78.41 \pm 2.00^{\mathrm{b}}$ & $75.99 \pm 1.36^{\mathrm{a}}$ & $77.05 \pm 0.61^{\mathrm{ab}}$ \\
Protein & $17.63 \pm 0.95^{\mathrm{b}}$ & $16.20 \pm 0.93^{\mathrm{ab}}$ & $17.37 \pm 1.25^{\mathrm{ab}}$ & $15.99 \pm 0.57^{\mathrm{a}}$ \\
Lipid & $1.27 \pm 0.12$ & $1.14 \pm 0.09$ & $1.26 \pm 0.06$ & $1.23 \pm 0.04$ \\
Ash & $1.97 \pm 0.14^{\mathrm{b}}$ & $1.77 \pm 0.07^{\mathrm{a}}$ & $1.79 \pm 0.16^{\mathrm{a}}$ & $2.05 \pm 0.08^{\mathrm{b}}$ \\
\hline
\end{tabular}

Notes: Data were presented as mean $\pm S D(n=6)$. Values in the same line with different superscripts were significantly different $(P<0.05)$.

The fatty acids composition in ovaries are reported in the Table 5. MD had the lowest percentage of HUFA because of the lowest 20:4n6, 20:5n3 and 22:6n3 levels, but the highest levels of C16:0, C17:0, and C18:1n9. Moreover, FD and PRC had a higher percentage of $\mathrm{C} 18: 2 \mathrm{n} 6$ and $20: 4 \mathrm{n} 6$, than the other treatments. The fatty acids composition in the hepatopancreas are shown in the Table 6. FD had the highest contents of $\mathrm{C} 14: 0, \mathrm{C} 18: 1 \mathrm{n} 9, \mathrm{C} 18: 3 \mathrm{n} 3$ and $20: 4 \mathrm{n} 6$ in hepatopancreas, but the lowest $\mathrm{C} 20: 1$ and C20:5n3 levels (Table 6). PRC had the highest value of C16:0 and C18:2n6 in hepatopancreas, while TF had the lowest levels of C18:2n6 and C18:3n3; MD had the highest level of HUFA, and PRC had the maximum of DHA/EPA ratio in hepatopancreas. Despite the feeding modes, all treatments had the similar fatty acids composition in the muscle (Table 7). TF had lower percentages of C18:2n6 and C20:5n3 than FD $(P<0.05)$, and PRC had the lowest levels of $\Sigma$ SFA and $\Sigma$ HUFA among all treatments $(P<0.05)$. 
Table 5. The effects of different feeding models on fatty acid profiles in the ovaries of female Portunus trituberculatus (\% of total fatty acids)

\begin{tabular}{|c|c|c|c|c|}
\hline Fatty acids & $\begin{array}{r}\text { Trash fish } \\
\text { (TF) }\end{array}$ & $\begin{array}{r}\text { Formulated diet } \\
\text { (FD) }\end{array}$ & $\begin{array}{r}\text { Mixture diets } \\
(M D)\end{array}$ & $\begin{array}{r}\text { Pond-reared control } \\
(P R C)\end{array}$ \\
\hline C14:0 & $1.71 \pm 0.19$ & $1.45 \pm 0.30$ & $1.84 \pm 0.37$ & $1.55 \pm 0.40$ \\
\hline C15:0 & $0.47 \pm 0.16$ & $0.48 \pm 0.13$ & $0.65 \pm 0.05$ & $0.55 \pm 0.12$ \\
\hline C16:0 & $15.82 \pm 0.90^{\mathrm{ab}}$ & $15.31 \pm 0.37^{a}$ & $17.65 \pm 1.89^{b}$ & $15.76 \pm 1.42^{\mathrm{ab}}$ \\
\hline $\mathrm{C} 17: 0$ & $0.52 \pm 0.02$ & $0.53 \pm 0.08$ & $1.08 \pm 0.72$ & $0.55 \pm 0.07$ \\
\hline C18:0 & $6.56 \pm 0.25$ & $6.66 \pm 1.19$ & $6.49 \pm 1.42$ & $6.72 \pm 1.15$ \\
\hline$\Sigma S F A$ & $25.38 \pm 1.24^{a}$ & $24.82 \pm 0.96^{\mathrm{a}}$ & $27.76 \pm 1.25^{\mathrm{b}}$ & $25.47 \pm 1.74^{a}$ \\
\hline $\mathrm{C} 16: 1$ & $6.72 \pm 0.27$ & $5.37 \pm 0.70$ & $7.33 \pm 1.56$ & $7.72 \pm 2.64$ \\
\hline $\mathrm{C} 17: 1$ & $0.73 \pm 0.03$ & $0.65 \pm 0.08$ & $0.64 \pm 0.12$ & $0.77 \pm 0.11$ \\
\hline C18:1n9 & $20.52 \pm 1.46^{\mathrm{ab}}$ & $20.16 \pm 1.18^{\mathrm{ab}}$ & $22.21 \pm 1.33^{b}$ & $18.12 \pm 1.57^{a}$ \\
\hline $\mathrm{C} 18: 1 \mathrm{n} 7$ & $5.04 \pm 0.15$ & $4.77 \pm 0.24$ & $5.18 \pm 0.38$ & $4.99 \pm 0.22$ \\
\hline C20:1 & $0.68 \pm 0.12$ & $0.97 \pm 0.31$ & $0.88 \pm 0.17$ & $0.71 \pm 0.14$ \\
\hline$\Sigma M U F A$ & $34.97 \pm 2.61^{\mathrm{ab}}$ & $32.12 \pm 1.07^{a}$ & $36.24 \pm 3.15^{b}$ & $32.55 \pm 2.44^{\mathrm{ab}}$ \\
\hline $\mathrm{C} 18: 2 \mathrm{n} 6$ & $1.56 \pm 0.08^{\mathrm{a}}$ & $2.54 \pm 0.78^{\mathrm{bc}}$ & $1.74 \pm 0.83^{\mathrm{ab}}$ & $2.79 \pm 0.35^{c}$ \\
\hline $\mathrm{C} 18: 3 \mathrm{n} 3$ & $0.26 \pm 0.04^{\mathrm{a}}$ & $0.31 \pm 0.08^{\mathrm{b}}$ & $0.30 \pm 0.03^{b}$ & $0.27 \pm 0.07^{a}$ \\
\hline $\mathrm{C} 20: 2 \mathrm{n} 6$ & $0.64 \pm 0.06$ & $1.16 \pm 0.87$ & $0.86 \pm 0.18$ & $1.00 \pm 1.01$ \\
\hline $\mathrm{C} 20: 4 \mathrm{n} 6$ & $2.42 \pm 0.17^{a b}$ & $2.51 \pm 0.17^{\mathrm{ab}}$ & $1.99 \pm 0.35^{\mathrm{a}}$ & $2.92 \pm 0.51^{b}$ \\
\hline$C 20: 5 n 3$ & $8.84 \pm 0.80$ & $8.54 \pm 0.33$ & $7.82 \pm 1.05$ & $8.86 \pm 1.01$ \\
\hline$C 22: 6 n 3$ & $18.41 \pm 1.17$ & $18.83 \pm 0.63$ & $16.29 \pm 1.24$ & $16.66 \pm 2.98$ \\
\hline$\Sigma$ PUFA & $32.66 \pm 2.00^{\mathrm{ab}}$ & $34.24 \pm 1.24^{b}$ & $29.27 \pm 1.92^{a}$ & $33.00 \pm 3.64^{\mathrm{ab}}$ \\
\hline n-3PUFA & $27.56 \pm 1.82^{\mathrm{ab}}$ & $27.82 \pm 0.70^{\mathrm{b}}$ & $24.41 \pm 2.04^{a}$ & $25.91 \pm 2.86^{\mathrm{ab}}$ \\
\hline n-6PUFA & $5.10 \pm 0.35^{\mathrm{a}}$ & $6.70 \pm 1.12^{\mathrm{b}}$ & $4.86 \pm 0.73^{a}$ & $7.09 \pm 0.90^{b}$ \\
\hline$n-3 / n-6$ & $5.42 \pm 0.36^{b}$ & $4.24 \pm 0.73^{\mathrm{ab}}$ & $5.13 \pm 1.02^{b c}$ & $3.67 \pm 0.23^{a}$ \\
\hline HUFA & $29.74 \pm 1.85^{b}$ & $30.05 \pm 0.59^{b}$ & $26.10 \pm 2.31^{\mathrm{a}}$ & $28.58 \pm 3.01^{\mathrm{ab}}$ \\
\hline DHA/EPA & $2.09 \pm 0.13$ & $2.21 \pm 0.12$ & $2.11 \pm 0.27$ & $1.91 \pm 0.45$ \\
\hline ARA/EPA & $0.28 \pm 0.04$ & $0.29 \pm 0.02$ & $0.26 \pm 0.04$ & $0.33 \pm 0.02$ \\
\hline
\end{tabular}

Notes: Data were presented as mean \pm SD $(n=5)$. Values in the same line with different superscripts were significantly different $(P<0.05)$. The fatty acid with less than $0.4 \%$ of total fatty acids was not shown in the table. SFA: saturated fatty acids; MUFA: mono-unsaturated fatty acids; PUFA: poly-unsaturated fatty acids; HUFA: highly-unsaturated fatty acids; $n-3 / n-6$ : the ratio of $\Sigma n-3 P U F A / \Sigma n-6 P U F A$.

Table 6. The effects of different feeding models on fatty acid profiles in the hepatopancreas of female Portunus trituberculatus (\% of total fatty acids)

\begin{tabular}{|c|c|c|c|c|c|}
\hline Fatty acids & Trash fish & Formulated diet & Mixture diets & Pond-reared control & \multirow{25}{*}{$\begin{array}{l}\text { Notes: Data were } \\
\text { presented as mean } \\
\pm \text { SD }(n=6) \text {. Values } \\
\text { in the same line with } \\
\text { different superscripts } \\
\text { were significantly } \\
\text { different }(P<0.05) \text {. } \\
\text { The fatty acid with } \\
\text { less than } 0.4 \% \text { of } \\
\text { total fatty acids was } \\
\text { not shown in the } \\
\text { table. SFA: } \\
\text { saturated fatty } \\
\text { acids; MUFA: mono- } \\
\text { unsaturated fatty } \\
\text { acids; PUFA: poly- } \\
\text { unsaturated fatty } \\
\text { acids; HUFA: highly- } \\
\text { unsaturated fatty } \\
\text { acids; } n-3 / n-6: \text { the } \\
\text { ratio of } \sum n- \\
\text { 3PUFA/ } \sum n-6 P U F A .\end{array}$} \\
\hline C14:0 & $2.70 \pm 0.13^{\mathrm{ab}}$ & $2.89 \pm 0.10^{\mathrm{b}}$ & $2.58 \pm 0.11^{a}$ & $2.65 \pm 0.30^{\mathrm{ab}}$ & \\
\hline C16:0 & $18.28 \pm 0.32^{\mathrm{ab}}$ & $17.53 \pm 0.83^{a}$ & $17.45 \pm 0.89^{a}$ & $18.62 \pm 0.46^{b}$ & \\
\hline C17:0 & $0.39 \pm 0.09$ & $0.55 \pm 0.11$ & $0.56 \pm 0.07$ & $0.40 \pm 0.17$ & \\
\hline C18:0 & $4.08 \pm 0.25$ & $3.79 \pm 0.19$ & $4.27 \pm 0.31$ & $3.81 \pm 0.42$ & \\
\hline$\Sigma$ SFA & $26.43 \pm 0.65$ & $25.70 \pm 0.89$ & $25.26 \pm 1.17$ & $26.23 \pm 0.86$ & \\
\hline $\mathrm{C} 16: 1$ & $9.36 \pm 0.51^{\mathrm{b}}$ & $7.05 \pm 0.39^{a}$ & $9.27 \pm 1.03^{b}$ & $9.16 \pm 0.65^{\mathrm{b}}$ & \\
\hline C18:1n9 & $24.62 \pm 1.49^{\mathrm{ab}}$ & $26.22 \pm 1.28^{\mathrm{b}}$ & $23.58 \pm 1.97^{a}$ & $24.23 \pm 1.42^{\mathrm{ab}}$ & \\
\hline $\mathrm{C} 18: 1 \mathrm{n} 7$ & $7.01 \pm 0.13^{b}$ & $6.63 \pm 0.40^{\mathrm{ab}}$ & $5.22 \pm 1.27^{\mathrm{a}}$ & $5.87 \pm 1.56^{\mathrm{ab}}$ & \\
\hline C20:1 & $2.03 \pm 0.76^{b}$ & $0.80 \pm 0.18^{a}$ & $0.83 \pm 0.40^{a}$ & $2.21 \pm 0.42^{b}$ & \\
\hline$\sum$ MUFA & $43.39 \pm 0.89^{b}$ & $41.31 \pm 1.45^{\mathrm{ab}}$ & $39.28 \pm 2.15^{\mathrm{a}}$ & $42.01 \pm 0.76^{b}$ & \\
\hline $\mathrm{C} 18: 2 \mathrm{n} 6$ & $1.06 \pm 0.20^{\mathrm{a}}$ & $2.39 \pm 0.33^{b}$ & $1.27 \pm 0.43^{\mathrm{a}}$ & $3.50 \pm 0.73^{c}$ & \\
\hline $\mathrm{C} 18: 3 \mathrm{n} 6$ & $0.47 \pm 0.34$ & $0.65 \pm 0.21$ & $0.78 \pm 0.45$ & $0.56 \pm 0.24$ & \\
\hline $\mathrm{C} 18: 3 \mathrm{n} 3$ & $0.15 \pm 0.11^{\mathrm{a}}$ & $0.55 \pm 0.39^{c}$ & $0.16 \pm 0.12^{\mathrm{a}}$ & $0.33 \pm 0.24^{\mathrm{ab}}$ & \\
\hline $\mathrm{C} 20: 2 \mathrm{n} 6$ & $1.19 \pm 0.19$ & $1.38 \pm 0.18$ & $0.91 \pm 0.58$ & $1.20 \pm 0.10$ & \\
\hline$C 20: 4 n 6$ & $1.17 \pm 0.12$ & $1.31 \pm 0.13$ & $1.38 \pm 0.18$ & $1.18 \pm 0.17$ & \\
\hline$C 20: 5 n 3$ & $5.35 \pm 0.29^{b}$ & $4.00 \pm 0.70^{a}$ & $5.57 \pm 1.01^{b}$ & $4.27 \pm 0.58^{a}$ & \\
\hline$C 22: 6 n 3$ & $10.77 \pm 0.35$ & $10.63 \pm 1.56$ & $11.97 \pm 1.85$ & $11.93 \pm 1.51$ & \\
\hline$\Sigma$ PUFA & $20.91 \pm 0.70$ & $20.19 \pm 3.15$ & $22.11 \pm 2.54$ & $24.28 \pm 2.40$ & \\
\hline n-3PUFA & $16.37 \pm 0.39$ & $15.35 \pm 1.81$ & $17.81 \pm 2.95$ & $16.77 \pm 2.13$ & \\
\hline n-6PUFA & $4.54 \pm 0.64^{a}$ & $4.84 \pm 1.78^{a}$ & $4.30 \pm 0.81^{a}$ & $7.50 \pm 0.79^{b}$ & \\
\hline$n-3 / n-6$ & $3.66 \pm 0.53$ & $3.64 \pm 1.14$ & $4.30 \pm 1.40$ & $2.25 \pm 0.32$ & \\
\hline HUFA & $17.68 \pm 0.43$ & $16.53 \pm 2.16$ & $19.27 \pm 2.93$ & $18.37 \pm 1.84$ & \\
\hline DHA/EPA & $2.02 \pm 0.15^{\mathrm{a}}$ & $2.70 \pm 0.46^{\mathrm{b}}$ & $2.16 \pm 0.13^{\mathrm{a}}$ & $2.81 \pm 0.28^{\mathrm{b}}$ & \\
\hline ARA/EPA & $0.22 \pm 0.03$ & $0.34 \pm 0.08$ & $0.25 \pm 0.02$ & $0.28 \pm 0.07$ & \\
\hline
\end{tabular}


Table 7. The effects of different feeding models on fatty acid profiles in the muscle of female Portunus trituberculatus (\% of total fatty acids)

\begin{tabular}{|c|c|c|c|c|c|}
\hline Fatty acids & Trash fish TF & Formalated diet FD & Mixed diet $M L$ & Pond-rear & \multirow{26}{*}{$\begin{array}{l}\text { Notes: Data were } \\
\text { presented as mean } \pm S D \\
(n=6) \text {. Values in the } \\
\text { same line with different } \\
\text { superscripts were } \\
\text { significantly different ( } P \\
<0.05) \text {. The fatty acid } \\
\text { with less than } 0.4 \% \text { of } \\
\text { total fatty acids was not } \\
\text { shown in the table. SFA: } \\
\text { saturated fatty acids; } \\
\text { MUFA: mono-unsaturated } \\
\text { fatty acids; PUFA: poly- } \\
\text { unsaturated fatty acids; } \\
\text { HUFA: highly- } \\
\text { unsaturated fatty acids; } \\
\text { n-3/n-6: the ratio of } \Sigma n- \\
\text { 3PUFA/ } \sum n-6 P U F A .\end{array}$} \\
\hline C14:0 & $1.11 \pm 0.13$ & $0.99 \pm 0.23$ & $1.05 \pm 0.13$ & $1.24 \pm 0.25$ & \\
\hline C15:0 & $0.58 \pm 0.09$ & $0.64 \pm 0.09$ & $0.60 \pm 0.10$ & $0.61 \pm 0.05$ & \\
\hline C16:0 & $14.72 \pm 1.02^{\mathrm{ab}}$ & $15.86 \pm 0.24^{b}$ & $14.29 \pm 0.4$ & $14.08 \pm 1.59^{a}$ & \\
\hline $\mathrm{C} 17: 0$ & $1.20 \pm 0.22^{\mathrm{b}}$ & $1.29 \pm 0.36^{\mathrm{b}}$ & $1.06 \pm 0.32^{\mathrm{b}}$ & $0.58 \pm 0.37^{a}$ & \\
\hline C18:0 & $6.13 \pm 0.18^{b}$ & $6.24 \pm 0.53^{b}$ & $5.96 \pm 0.21^{b}$ & $5.33 \pm 0.58^{\mathrm{a}}$ & \\
\hline$\Sigma S F A$ & $24.34 \pm 1.50^{\mathrm{bc}}$ & $25.58 \pm 0.73^{c}$ & $23.59 \pm 0.6$ & $22.10 \pm 1.98^{\mathrm{a}}$ & \\
\hline C16:1 & $5.22 \pm 0.49$ & $4.08 \pm 1.37$ & $4.48 \pm 0.42$ & $4.70 \pm 0.84$ & \\
\hline C17:1 & $0.62 \pm 0.07$ & $0.52 \pm 0.18$ & $0.53 \pm 0.33$ & $0.48 \pm 0.09$ & \\
\hline C18:1n9 & $18.76 \pm 0.85$ & $18.94 \pm 1.20$ & $17.69 \pm 0.8$ & $18.31 \pm 1.56$ & \\
\hline C18:1n7 & $4.23 \pm 0.11^{\mathrm{ab}}$ & $4.10 \pm 0.30^{\mathrm{ab}}$ & $3.52 \pm 0.84^{a}$ & $4.51 \pm 0.48^{b}$ & \\
\hline C20:1 & $0.34 \pm 0.17$ & $0.41 \pm 0.08$ & -- & $0.41 \pm 0.05$ & \\
\hline$\Sigma$ MUFA & $24.49 \pm 9.71$ & $28.89 \pm 2.05$ & $29.26 \pm 1.3$ & $28.40 \pm 1.47$ & \\
\hline $\mathrm{C} 18: 2 \mathrm{n} 6$ & $1.73 \pm 0.35^{\mathrm{a}}$ & $2.56 \pm 0.89^{a b}$ & $2.88 \pm 0.87^{b}$ & $3.83 \pm 0.66^{c}$ & \\
\hline $\mathrm{C} 18: 3 \mathrm{n} 3$ & $0.26 \pm 0.12$ & $0.46 \pm 0.05$ & $0.35 \pm 0.09$ & $0.41 \pm 0.06$ & \\
\hline $\mathrm{C} 20: 2 \mathrm{n} 6$ & $0.80 \pm 0.05$ & $0.74 \pm 0.25$ & $0.80 \pm 0.11$ & $0.77 \pm 0.06$ & \\
\hline$C 20: 4 n 6$ & $2.95 \pm 0.53^{b}$ & $2.78 \pm 0.28^{b}$ & $2.93 \pm 0.24^{b}$ & $2.14 \pm 0.06^{a}$ & \\
\hline$C 20: 5 n 3$ & $18.04 \pm 0.60^{\mathrm{ab}}$ & $19.56 \pm 1.20^{\mathrm{b}}$ & $18.31 \pm 0.7$ & $16.90 \pm 1.22^{\mathrm{a}}$ & \\
\hline $\mathrm{C} 22: 6 \mathrm{n} 3$ & $16.70 \pm 1.10$ & $16.12 \pm 0.49$ & $17.66 \pm 0.8$ & $16.55 \pm 2.51$ & \\
\hline ¿PUFA & $40.88 \pm 1.23$ & $42.88 \pm 2.11$ & $43.41 \pm 1.1$ & $40.61 \pm 4.00$ & \\
\hline n-3PUFA & $35.04 \pm 1.27$ & $36.05 \pm 1.05$ & $36.38 \pm 1.3$ & $33.86 \pm 3.40$ & \\
\hline n-6PUFA & $5.84 \pm 0.32$ & $6.84 \pm 2.04$ & $7.03 \pm 0.69$ & $6.75 \pm 0.64$ & \\
\hline$n-3 / n-6$ & $6.02 \pm 0.44$ & $5.60 \pm 1.48$ & $5.22 \pm 0.67$ & $5.01 \pm 0.15$ & \\
\hline HUFA & $37.87 \pm 1.36^{\mathrm{ab}}$ & $38.95 \pm 1.51^{b}$ & $39.01 \pm 1.6$ & $35.60 \pm 3.36^{a}$ & \\
\hline DHA/EPA & $0.93 \pm 0.07^{\mathrm{ab}}$ & $0.83 \pm 0.06^{\mathrm{a}}$ & $0.96 \pm 0.04^{b}$ & $0.98 \pm 0.13^{b}$ & \\
\hline ARA/EPA & $0.16 \pm 0.03$ & $0.14 \pm 0.01$ & $0.16 \pm 0.01$ & $0.13 \pm 0.01$ & \\
\hline
\end{tabular}

Amino acid content in the ovaries are shown in Table 8 . The content of essential amino acids (EAA), non-essential amino acids (NEAA), and total amino acids (TAA) fluctuated within the following ranges: $13.28-13.92 \mathrm{mg} / \mathrm{g}$ for EAA, $14.67-14.82 \mathrm{mg} / \mathrm{g}$ for NEAA, as well as $27.95-28.68 \mathrm{mg} / \mathrm{g}$ for TAA. FD had a slightly lower EAA and TAA content in the ovaries than the other treatments. In EAA, the valine, isoleucine, leucine, and lysine content was greater than $1.5 \%$, while glutamic acid had the highest NEAA value of around $4 \%$ in the ovaries.

Table 8. The effects of different feeding models on amino acids contents in the ovary of female Portunus trituberculatus (\% tissue wet weight)

\begin{tabular}{|c|c|c|c|c|c|}
\hline Amino acids & Trash fish TF & Formulated diet FD & Mixed diet $M D$ & Pond-reared & \multirow{23}{*}{$\begin{array}{l}\text { Notes: Data were } \\
\text { presented as mean } \pm \\
\text { SD }(n=3) \text {. Values in the } \\
\text { same line with different } \\
\text { superscripts were } \\
\text { significantly different ( } P \\
<0.05) \text {; EAA: essential } \\
\text { fatty acids; NEAA: non- } \\
\text { essential fatty acids; } \\
\text { TAA: total amino acids. }\end{array}$} \\
\hline Isoleucine & $1.48 \pm 0.03$ & $1.50 \pm 0.04$ & $1.55 \pm 0.02$ & $1.51 \pm 0.05$ & \\
\hline Leucine & $2.44 \pm 0.06$ & $2.47 \pm 0.07$ & $2.52 \pm 0.04$ & $2.62 \pm 0.10$ & \\
\hline Lysine & $2.07 \pm 0.08$ & $1.95 \pm 0.10$ & $2.10 \pm 0.02$ & $2.12 \pm 0.00$ & \\
\hline Methionine & $0.72 \pm 0.10$ & $0.65 \pm 0.09$ & $0.68 \pm 0.05$ & $0.54 \pm 0.09$ & \\
\hline Cysteine & $0.29 \pm 0.00$ & $0.25 \pm 0.04$ & $0.23 \pm 0.02$ & $0.25 \pm 0.03$ & \\
\hline Phenylalanine & $1.12 \pm 0.04$ & $1.15 \pm 0.04$ & $1.16 \pm 0.02$ & $1.18 \pm 0.03$ & \\
\hline Tyrosine & $1.38 \pm 0.04$ & $1.34 \pm 0.02$ & $1.42 \pm 0.02$ & $1.43 \pm 0.04$ & \\
\hline Threonine & $1.46 \pm 0.05$ & $1.47 \pm 0.05$ & $1.49 \pm 0.03$ & $1.58 \pm 0.06$ & \\
\hline Valine & $1.78 \pm 0.06$ & $1.81 \pm 0.05$ & $1.85 \pm 0.03$ & $1.87 \pm 0.03$ & \\
\hline Tryptophan & $0.83 \pm 0.06$ & $0.68 \pm 0.07$ & $0.80 \pm 0.07$ & $0.81 \pm 0.05$ & \\
\hline EAA & $13.58 \pm 0.50$ & $13.28 \pm 0.57$ & $13.82 \pm 0.31$ & $13.92 \pm 0.47$ & \\
\hline Aspartic acid & $2.27 \pm 0.05$ & $2.29 \pm 0.07$ & $2.33 \pm 0.31$ & $2.43 \pm 0.13$ & \\
\hline Serine & $1.82 \pm 0.38$ & $1.59 \pm 0.05$ & $1.61 \pm 0.03$ & $1.67 \pm 0.08$ & \\
\hline Glutamic acid & $3.79 \pm 0.08$ & $3.87 \pm 0.13$ & $3.92 \pm 0.09$ & $4.02 \pm 0.20$ & \\
\hline Glycine & $1.18 \pm 0.02$ & $1.16 \pm 0.06$ & $1.19 \pm 0.01$ & $1.17 \pm 0.02$ & \\
\hline Alanine & $1.22 \pm 0.04$ & $1.24 \pm 0.04$ & $1.25 \pm 0.02$ & $1.27 \pm 0.04$ & \\
\hline Histidine & $0.86 \pm 0.03$ & $0.87 \pm 0.02$ & $0.86 \pm 0.05$ & $0.82 \pm 0.02$ & \\
\hline Arginine & $1.94 \pm 0.04$ & $2.05 \pm 0.15$ & $2.04 \pm 0.08$ & $1.97 \pm 0.05$ & \\
\hline Proline & $1.66 \pm 0.13$ & $1.60 \pm 0.10$ & $1.62 \pm 0.12$ & $1.39 \pm 0.01$ & \\
\hline NEAA & $14.73 \pm 0.78$ & $14.67 \pm 0.62$ & $14.82 \pm 0.34$ & $14.76 \pm 0.53$ & \\
\hline TAA & $28.31 \pm 1.09$ & $27.95 \pm 1.16$ & $28.64 \pm 0.57$ & $28.68 \pm 0.68$ & \\
\hline EAA/TAA & $0.48 \pm 0.01$ & $0.48 \pm 0.00$ & $0.48 \pm 0.00$ & $0.49 \pm 0.01$ & \\
\hline
\end{tabular}


Table 9 presents the amino acids content in the muscle. Except for the contents of cysteine and methionine, different feeding modes had significant effects on content of all the other EAA. Overall, muscle EAA of TF had significantly higher content for most of EAA than FD, and MD and PRC had the middle content of EAA among four treatments. As for NEAA, TF had significantly higher contents of aspartic acid, histidine, and arginine. In terms of muscle TAA, the lowest content was found in the FD and PRC, and TF had the highest TAA content.

Table 9. The effects of different feeding models on amino acids contents in the muscle of female Portunus trituberculatus (\% tissue wet weight)

\begin{tabular}{|c|c|c|c|c|}
\hline Amino acids & $\begin{array}{l}\text { Trash fish } \\
\text { (TF) }\end{array}$ & $\begin{array}{l}\text { Formulated diet } \\
\text { (FD) }\end{array}$ & $\begin{array}{l}\text { Mixed diets } \\
\text { (MD) }\end{array}$ & $\begin{array}{l}\text { Pond-reared control } \\
\text { (PRC) }\end{array}$ \\
\hline Isoleucine & $0.75 \pm 0.04^{b}$ & $0.66 \pm 0.01^{a}$ & $0.71 \pm 0.02^{\mathrm{ab}}$ & $0.64 \pm 0.02^{a}$ \\
\hline Leucine & $1.22 \pm 0.06^{\mathrm{b}}$ & $1.08 \pm 0.03^{a}$ & $1.17 \pm 0.03^{\mathrm{ab}}$ & $1.51 \pm 0.04^{c}$ \\
\hline Lysine & $1.31 \pm 0.05^{b}$ & $1.15 \pm 0.03^{a}$ & $1.25 \pm 0.02^{\mathrm{ab}}$ & $1.26 \pm 0.05^{\mathrm{ab}}$ \\
\hline Methionine & $0.31 \pm 0.01$ & $0.30 \pm 0.04$ & $0.31 \pm 0.02$ & $0.29 \pm 0.02$ \\
\hline Cysteine & $0.20 \pm 0.00$ & $0.19 \pm 0.02$ & $0.21 \pm 0.02$ & $0.18 \pm 0.02$ \\
\hline Phenylalanine & $0.68 \pm 0.04^{b}$ & $0.59 \pm 0.01^{\mathrm{a}}$ & $0.61 \pm 0.03^{\mathrm{ab}}$ & $0.64 \pm 0.00^{\mathrm{ab}}$ \\
\hline Tyrosine & $0.66 \pm 0.05^{b}$ & $0.57 \pm 0.00^{\mathrm{a}}$ & $0.63 \pm 0.02^{\mathrm{ab}}$ & $0.58 \pm 0.02^{\mathrm{ab}}$ \\
\hline Threonine & $0.70 \pm 0.04^{b}$ & $0.61 \pm 0.01^{a}$ & $0.66 \pm 0.02^{\mathrm{ab}}$ & $0.64 \pm 0.03^{\mathrm{ab}}$ \\
\hline Valine & $0.74 \pm 0.01^{c}$ & $0.68 \pm 0.01^{a}$ & $0.73 \pm 0.02^{b c}$ & $0.70 \pm 0.02^{\mathrm{ab}}$ \\
\hline Tryptophan & $0.27 \pm 0.01^{b}$ & $0.19 \pm 0.01^{a}$ & $0.24 \pm 0.00^{\mathrm{ab}}$ & $0.20 \pm 0.04^{a}$ \\
\hline EAA & $6.84 \pm 0.32^{b}$ & $6.03 \pm 0.19^{a}$ & $6.51 \pm 0.21^{\mathrm{ab}}$ & $6.29 \pm 0.27^{a}$ \\
\hline Aspartic acid & $1.61 \pm 0.09^{b}$ & $1.40 \pm 0.03^{a}$ & $1.51 \pm 0.05^{\mathrm{ab}}$ & $1.45 \pm 0.08^{\mathrm{ab}}$ \\
\hline Serine & $0.63 \pm 0.03$ & $0.56 \pm 0.02$ & $0.60 \pm 0.02$ & $0.58 \pm 0.04$ \\
\hline Glutamic acid & $2.55 \pm 0.08$ & $2.37 \pm 0.08$ & $2.44 \pm 0.06$ & $2.38 \pm 0.03$ \\
\hline Glycine & $1.35 \pm 0.04^{\mathrm{b}}$ & $1.19 \pm 0.12^{\mathrm{ab}}$ & $1.27 \pm 0.04^{\mathrm{ab}}$ & $1.07 \pm 0.07^{a}$ \\
\hline Alanine & $1.05 \pm 0.10^{\mathrm{b}}$ & $0.98 \pm 0.00^{\mathrm{ab}}$ & $1.01 \pm 0.01^{\mathrm{ab}}$ & $0.91 \pm 0.01^{a}$ \\
\hline Histidine & $0.47 \pm 0.03^{b}$ & $0.41 \pm 0.01^{a}$ & $0.45 \pm 0.03^{\mathrm{ab}}$ & $0.40 \pm 0.01^{a}$ \\
\hline Arginine & $1.61 \pm 0.07^{b}$ & $1.43 \pm 0.04^{\mathrm{a}}$ & $1.55 \pm 0.02^{\mathrm{ab}}$ & $1.66 \pm 0.07^{b}$ \\
\hline Proline & $1.49 \pm 0.08$ & $1.22 \pm 0.03$ & $1.47 \pm 0.17$ & $1.27 \pm 0.04$ \\
\hline NEAA & $10.75 \pm 0.54^{b}$ & $9.56 \pm 0.27^{a}$ & $10.30 \pm 0.23^{\mathrm{ab}}$ & $9.71 \pm 0.23^{a}$ \\
\hline TAA & $17.59 \pm 0.82^{b}$ & $15.59 \pm 0.46^{a}$ & $16.80 \pm 0.28^{\mathrm{ab}}$ & $16.00 \pm 0.42^{a}$ \\
\hline EAA/TAA & $0.39 \pm 0.00$ & $0.39 \pm 0.00$ & $0.39 \pm 0.00$ & $0.39 \pm 0.00$ \\
\hline
\end{tabular}

Notes: Data were presented as mean $\pm S D(n=3)$. Values in the same line with different superscripts were significantly different $(P<0.05)$; EAA: essential fatty acids; NEAA: non-essential fatty acids; TAA: total amino acids.

Table 10 shows the essential amino acids score (EAAS) of ovaries and muscle according to the standard of FAO/WHO/UNU. In both, ovaries and muscle, EAAS was greater than 100 in all treatments, indicating there was no limiting amino acids. For mean EAAS of ovaries and muscle, TF had the highest EAAS, while the lowest EAAS was observed in the FD.

Table 10. The effect of different diets on essential amino acids score for the ovary and muscle of female Portunus trituberculatus

\begin{tabular}{|c|c|c|c|c|c|c|c|c|}
\hline \multirow[b]{2}{*}{$E A A$} & \multicolumn{4}{|l|}{ Ovary } & \multicolumn{4}{|l|}{ Muscle } \\
\hline & $\begin{array}{l}\text { Trash } \\
\text { fish } \\
(T F)\end{array}$ & $\begin{array}{l}\text { Formulated } \\
\text { diet (FD) }\end{array}$ & $\begin{array}{l}\text { Mixture } \\
\text { diets } \\
(M D)\end{array}$ & $\begin{array}{l}\text { Pond-reared } \\
\text { control } \\
(P R C)\end{array}$ & $\begin{array}{l}\text { Trash } \\
\text { fish } \\
\text { (TF) }\end{array}$ & $\begin{array}{l}\text { Formulated } \\
\text { diet (FD) }\end{array}$ & $\begin{array}{l}\text { Mixed } \\
\text { diets } \\
(M D)\end{array}$ & $\begin{array}{l}\text { Pond-reared } \\
\text { control } \\
\text { (PRC) }\end{array}$ \\
\hline Isoleucine & 182 & 177 & 186 & 178 & 151 & 145 & 145 & 144 \\
\hline Leucine & 127 & 124 & 128 & 131 & 105 & 101 & 102 & 109 \\
\hline Lysine & 123 & 111 & 122 & 121 & 128 & 122 & 124 & 136 \\
\hline Methionine + & 139 & 118 & 123 & 105 & 116 & 122 & 120 & 117 \\
\hline Phenylalanine & 136 & 131 & 138 & 137 & 121 & 114 & 113 & 121 \\
\hline Threonine & 148 & 143 & 148 & 154 & 117 & 111 & 112 & 118 \\
\hline Valine & 260 & 205 & 245 & 245 & 137 & 109 & 123 & 115 \\
\hline Tryptophan & 175 & 170 & 177 & 177 & 120 & 119 & 120 & 124 \\
\hline Mean value & 161 & 147 & 158 & 156 & 125 & 118 & 120 & 123 \\
\hline
\end{tabular}

Notes: $\mathrm{EAAS}=100 \times$ one essential fatty acid content in sample/one essential fatty acid content in FAO reference protein (FAO/WHO/UNU, 1985). 


\section{Discussion}

Feeding adult $P$. trituberculatus crabs with immature gonads (at the puberty molting stage) with a high-quality diet (defined as "fattening" in crab aquaculture industry) is very important to improve nutritional composition and market price of female animals (Wu et al., 2014). Although fattening culture of female $P$. trituberculatus could not significantly improve body weight, it would improve the quality and economic value of pond-reared females. Therefore, fattening females with immature ovaries has been considered an important technique for pond-culture of $P$. trituberculatus (Wu et al., 2014). The present study clearly showed that different fattening feed strategies could affect ovarian development, meat yield (MY), and survival. Compared to the formulated diet (FD), both trash fish (TF) and mixed diets (MD) improved gonadal development for females. The possible reason may be due to the quick shift from trash fish in outdoor ponds before the experiments to formulated diet fed to the females from FD treatment, which may lead to the limited uptake of FD during the early stage of fattening. Similar findings were observed for many marine Penaeus species during the broodstock culture process (Wouters et al., 2001; Naessenes et al., 1997). For aquatic animals, it is commonly acknowledged that the juvenile animals can more easily accept food shifts from fresh food to formulated diet than the adults or pre-adults (Johnston et al., 2008). Therefore, diet shifts should be conducted during the early culture stage for female $P$. trituberculatus, which could improve the fattening performance (Wu et al., 2014). Moreover, the minimum GSI was observed in pond-reared control treatment, which may be ascribed to the lower water temperature of outdoor ponds (Pan et al., 2015). Interestingly, FD treatment had the highest survival, and the lowest survival was in the TF treatment, which is similar for the pre-adult P. trituberculatus (Hou et al., 2016). Previous study has shown that frozen trash fish may contain a certain concentration of toxins, such as histamine, heavy metals, and pathogens, which have negative impacts on survival, and on growth and gonadal development in crustaceans (Zhang et al., 2012). Clearly, formulated diets may be major hindrances for the sustainable development of aquaculture industry of $P$. trituberculatus, therefore, it has become very important to develop effective formulated diets to replace trash fish.

This study indicated that formulated diets can basically meet nutritional requirements during the ovarian development of female $P$. trituberculatus. However, the females had a lower feeding ratio for FD during the early fattening, while TF was more palatable, leading to higher feeding ratio and higher GSI, than that of FD treatment. Therefore, currently, mixed diets with formulated diet and trash fish are more feasible and effective for the fattening practice. Taken together, if formulated diet was widely applied in aquaculture to replace commonly used trash fish and low value bivalves, future studies should be conducted to improve nutrient composition and decrease formulation costs. Moreover, more attention should be paid to the palatability of formulated diets to improve the feeding ratio during the fattening period of female $P$. trituberculatus.

The moisture content of the hepatopancreas and muscle in FD was higher, and also had the lowest content of crude protein and total lipids. This could be explained by the insufficient intake of formulated diet, and that the stored nutrients in hepatopancreas were transferred to the developing ovaries, leading to the lower hepatosomatic index (HSI) as well as the lower nutrient content. Meanwhile, TF treatment had the highest ash content in all three edible tissues, which may be related to high ash content of trash fish. Overall, the proximate composition of edible tissues in MD treatment was close to that of TF. These results suggested that the feeding of MD was beneficial for ovarian development and nutrient accumulation of female $P$. trituberculatus. Pond-reared females had lower crude protein in the muscle than the other treatments, which could be explained by the low water temperature, and thus reduced feed intake, in the outdoor ponds during the winter period, as previously documented (Pan et al, 2015).

Overall, fatty acids composition of the three edible tissues had certain relevance with regard to the fatty acid composition of their feeds, especially for the contents of $18: 1 \mathrm{n} 9$, $18: 2 n 6,18: 3 n 3,20: 5 n 3$ as well as DHA/EPA ratio in the hepatopancreas. In the present study, no differences were found in 20:4n6, 20:5n3 and 22:6n3 in ovaries and muscle between the three feeding modes. This could be due to two reasons. (1) Female ovaries need high amounts of HUFA to ensure normal ovarian development, and the animal 
priorities deposition of these nutrients in the gonads. Accordingly, the composition of HUFA had the certain conservative characteristic (Wu et al., 2014), which maybe lead to the similar HUFA composition among the treatments. (2) Before or nearly after molting, fatty acids composition of muscle of $P$. trituberculatus was more easily affected by dietary fatty acids, because the fatty acids were quickly transported from hepatopancreas to the muscle (Yang et al, 2013). This experiment started around 20-30 days of postpuberty molting and therefore fatty acid composition of muscle was relatively stable and not significantly influenced by their diets. Although formulated diet contained $23.8 \%$ of $18: 2 n 6$, only $2-3 \%$ of $18: 2 n 6$ was found in the ovaries, hepatopancreas, and muscle in FD treatment. This was because $P$. trituberculatus is a typical marine crustacean species, which had limited dietary requirement for n-6 PUFA (Zhang et al., 2014). Accordingly, previous research showed that wild swimming crab had the low level of 18:2n6 (Xu et al., 2009). Therefore, the dietary excessive amount of 18:2n6 was absorbed firstly in the hepatopancreas, then was likely oxidized to provide energy sources, rather than accumulated in the tissues.

Although amino acids composition and contents of diets varied significantly among three feeding modes, similar amino acids composition was detected in the ovaries among three treatments, which indicated female $P$. trituberculatus had a rather stable amino acid composition in the ovaries (Wu et al., 2009). FD treatment had the lowest content for most amino acids in the muscle, which may be due to lower food intake of this treatment as well as the lower crude protein and amino acids contents in formulated diet than those of the other diets.

\section{Acknowledgements}

This study was funded by the research and extension projects (No. 2016-1-18) from Shanghai Agriculture Committee. Analysis costs were partially supported by two projects (No.40806068 and No.41276158) from the Natural Science Foundation of China. Infrastructure costs were partially supported by the research project (No. A1-2801-181003) for high level university in Shanghai from Shanghai Municipal Education Committee and Collaborative Innovation Project for Mari-culture industry in East China Sea from Ningbo University.

\section{References}

AOAC., 1995. Official methods of analysis of the AOAC. Arlington, VA, USA: Association of Official Analytical Chemists.

Bureau of Fisheries and Fishery Management, Ministry of Agriculture of China., 2017. China fisheries statistical yearbook in 2018. Beijing: Chinese Agricultural Press.

Chen D., Zhang M. and S. Shrestha, 2007. Compositional characteristics and nutritional quality of Chinese mitten crab (Eriocheir sinensis). Food Chemistry, 103(4): 1343-1349.

Ding X., He Z., Qiu X., Huang F. and H. Xue, 2010. A study on digestive enzyme activities and their effects by compound feed during different growth stages of Portunus trituberculatus. Chinese J Anim Nutr, 22(2): 492-497.

Duan Q., Mai K., Shentu J., Gao Q. and J. Yang, 2013. Effects of dietary protein and lipid levels on growth and ovary pigmentation in Portunus trituberculatus. J Fish Sci China, 4(18): 809-818.

Fao/Who/UNU., 1985. Energy and protein requirements; report of a joint FAO/ WHO/UNU expert consultation; World Health Organization Technical Report Series 724. Geneva, Switzerland: WHO.

Folch J., Lees M. and G. Stanley, 1957. A simple method for the isolation and purification of total lipids from animal tissues. J Biol Chem, 226: 495-509.

Hou W., Pan G., Long X., Wu X., Zhou W. and Y. Cheng, 2016. Effects of three diets on survival, molting, growth and biochemical composition of pre-adult Portunus trituberculatus. Chinese J Zool, 51(4): 642-654.

Jin M., Wang M., Hou Y., Huang W., Hou Y., Ding L. and Q. Zhou, 2015. Dietary methionine requirement of juvenile swimming crab (Portunus trituberculatus). Chinese $J$ Anim Nutr, 27(11): 3457-3467. 
Johnston M., Johnston D. and C. Jones, 2008. Evaluation of partial replacement of live and fresh feeds with a formulated diet and the influence of weaning Panulirus ornatus phyllosomata onto a formulated diet during early ontogeny. Aquacult Int, 16(1): 33-47.

Li Y., Zhang W., Jin M., Hou Y., Qiu H., Hou Y. and Q. Zhou, 2015. Effects of dietary vitamin $E$ level on growth performance, serum non-specific immune and anti-oxidant indices of juvenile swimming crab (Portunus tribueculatus). Chinese J Anim Nutr, 27(5): 1431-1439.

Morrison W. and L. Smith, 1964. Preparation of fatty acid methyl esters and dimethyl acetals from lipid with boron florides-methanol. J Lipid Res, 5: 600-608.

Naessens E., Lavens P., Gomez L., Browdy C., Mcgovernhopkins K., Spencer A., Kawahigashi D. and P. Sorgeloos, 1997. Maturation performance of Penaeus vannamei co-fed artemia biomass preparations. Aquaculture, 155(97): 87-101.

Pan G., Hou W., Wu X., Wu R., Zhang N., Long X., Zhou W. and Y. Cheng, 2015. Effects of water temperature and single crab basket culture on ovarian development and tissue proximate composition of female Portunus trituberculatus. Mar Fish, 37(6): 550556.

Qiao Z. and X. Gu, 2012. Progress of the crab seed cultivation in earthen pond in China. Mar Fish, 34(1): 112-114.

Spindler M., Stadler R. and H. Tanner, 1985. Amino acid analysis of feedstuffs: determination of methionine and cystine after oxidation with performic acid and hydrolysis. J Agr Food Chem, 32(6): 24-26.

Wang C., Mu C., Li R., Song H., Yi X and C. Han, 2013. Culture technology of high yield and high efficiency for Portunus trituberculatus using single crab culture in individual basket system. China Fisheries, 1(1): 72-75.

Wouter R., Lavens P., Nieto J. and P. Sorgeloos, 2001. Penaeid shrimp broodstock nutrition: an updated review on research and development. Aquaclture, 202(1): 1-21.

Wu X., Wang Q., Lou B., Liu Z. and Y. Cheng, 2014. Effects of fattening period on ovarian development and nutritional quality of female swimming crab (Portunus trituberculatus). J Fish China, 38(2): 170-175.

Wu X., Cheng Y., Zeng C., Wang C. and X. Yang, 2010a. Reproductive performance and offspring quality of wild-caught and pond-reared swimming crab (Portunus trituberculatus) broodstock. Aquaculture, 301(1-4): 78-64.

Wu X., Zhou B., Cheng Y., Zeng C., Wang C. and L. Feng, 2010b. Comparison of gender differences in biochemical composition and nutritional value of various edible parts of the blue swimmer crab. J Food Compos Anal, 23(2): 154-159.

Xie Z., Liu H. and L. Feng, 2002. Seawater economy crab culture technology (pp. 1527). Beijing, China Agricul Ture Press.

Xu S., Zhang W., Yan X. and H. Lv, 2009. Analysis and comparison of nutritional quality between wild and cultured Portunnus trituberculatus. Chinese J Anim Nutr, 21(5): 695-702.

Yang Y., Wu X., Wang W., Liu Z., Lou B. and Y. Cheng, 2013. Effects of purified diet, fresh foods and mixed diets on the survival, growth performance and biochemical composition of juvenile swimming crab, Portunus trituberculatus. J Shanghai Ocean University, 22(2): 232-239.

Zhang J., Yang X., Fan P., Zhao L., Wang C., Yang Z., Hong Y. and Y. Cheng, 2012. Changes in total volatile basic nitrogen and biogenic amines in two common species of marine fish at high temperature. Acta Hydrobiol Sinica, 36(2): 284-290.

Zhang W., Xie F., Jin M., Zhou Q., Li M. and C. Han, 2014. Effects of dietary n-3 highly unsaturated fatty acid content on growth performance and fatty acid composition of juvenile swimming crab (Portunus trituberculatus). Chinese J Anim Nutr, 26(5):12541264. 